\title{
Chromosomal mapping of two Mariner-like elements in the grasshopper Abracris flavolineata (Orthoptera: Acrididae) reveals enrichment in euchromatin
}

\author{
Octavio M. PALACIOS-GIMENEZ, Danilo BUENO and Diogo C. CABRAL-DE-MELLO*
}

UNESP - Univ. Estadual Paulista, Instituto de Biociências/IB, Departamento de Biologia, CEP 13506-900 Rio Claro, SP, Brazil; e-mails: mellodc@rc.unesp.br; opalacios7@gmail.com; danilo_riber@yahoo.com.br

Key words. Orthoptera, Acrididae, B chromosome, euchromatin, FISH, genome, grasshopper, repetitive DNA, transposable elements

\begin{abstract}
The occurrence of transposable elements (TEs) is a ubiquitous characteristic of eukaryotic genomes, and these sequences are highly abundant in some species. Due to their large genomes, grasshoppers (Orthoptera) appear to be potentially good candidates in terms of having genomes that harbour considerable numbers of TEs. In the present study, we have investigated the occurrence of two Mariner-like elements (MLEs) within the genome of the grasshopper, Abracris flavolineata (De Geer, 1773), describing their distribution in both the A (i.e. standard or normal) complement and B chromosomes. PCR amplification followed by cloning and sequencing revealed two Mariner-like elements, which were named Afmarl and Afmar2. Moreover, subsequent fluorescence in situ hybridization (FISH) assays indicated an abundance of these elements in the euchromatic regions of all the standard complement chromosomes and an absence of such sequences in heterochromatic regions. These sequences were also abundant in the euchromatic B chromosome: Afmarl was distributed along the entire length of the chromosome, whereas Afmar2 was restricted to the proximal/interstitial regions of the chromosomal long arm. The general aspects of the distribution patterns of the two MLEs are discussed as well as their possible involvement in the origin and diversification of the $\mathrm{B}$ chromosome in A. flavolineata.
\end{abstract}

\section{INTRODUCTION}

The occurrence of multiple copies of identical or similar repetitive DNA sequences is a common feature of eukaryotic genomes. Among these sequences are transposable elements (TEs), which are ubiquitous in most eukaryotes and may comprise a large portion of the DNA in some species (cf. Hurst \& Werren, 2001; Lander et al., 2001; Kidwell, 2002; Biémont \& Vieira, 2006; Feschotte \& Pritham, 2007; Charles et al., 2008; Osanai-Futahashi et al., 2008; Hua-Van et al., 2011). TEs have a capacity for movement between non-homologous sites (a common feature of TEs). TEs can change their specific locations in genomes, and this movement can influence their accumulation and the generation of polymorphisms. Due to these characteristics, TEs were first considered selfish genetic elements or genomic parasites (Doolittle \& Sapienza, 1980; Orgel \& Crick, 1980). However, it is currently believed that they can influence the architecture and function of genomes; indeed, TEs are considered an important driving force for genomic reorganization and evolution (Kazazian, 2004; Biémont \& Vieira, 2006; Feschotte \& Pritham, 2007; Böhne et al., 2008; Biémont, 2010; Hua-Van et al., 2011).

TEs are classified into two classes according to their structure and mechanism of transposition: class I (retrotransposons) and II (transposons), using RNA as an intermediate or transposing directly as DNA, respectively (Wicker et al., 2007; Kapitonov \& Jurka, 2008). Among the transposons, the Mariner elements constitute a superfamily of widespread elements and have been observed in several groups of organisms (Langin et al., 1995; Augé-
Gouillou et al., 1995; Plasterk et al., 1999; Feschotte \& Wessler, 2002; Witherspoon \& Robertson, 2003; Jacobs et al., 2004; Sinzelle et al., 2006). Mariner elements are approximately $1,300 \mathrm{bp}$ long and are flanked by a terminal inverted repeat (TIR) of 28-32 bp; the element consists of a single intron-less gene that encodes for the transposase, which is responsible for the transposition mechanism, including excision, transfer and DNA strand repair (Lampe et al., 1996; Wicker et al., 2007).

Supernumerary B chromosomes have been considered for some time to represent another class of "selfish" genetic element, occurring in more than 1,500 animals and plants and possessing mechanisms for accumulation. Most B chromosomes are heterochromatic and are mainly composed of several types of repetitive DNAs, such as TEs, distinct multigene families, and satellite DNAs (Camacho, 2005; Houben et al., 2013). The South American grasshopper species Abracris flavolineata (De Geer, 1773) (Orthoptera: Acrididae) possesses a karyotype composed of $2 \mathrm{n}=23$, X0 (males) with heterochromatin (revealed by Cbanding) concentrated in the centromeric region, extending to the short arms of all chromosomes; additionally, $30.7 \%$ of the individuals from a population collected in the vicinity of Rio Claro, São Paulo, Brazil, harbour one or two distinct submetacentric B chromosomes that are entirely euchromatic (Bueno et al., 2013). To understand the chromosomal organization of TEs, with an emphasis on the $\mathrm{B}$ chromosome, we analyzed two distinct Mariner-like elements $(M L E)$ that exist in the A. flavolineata genome. Our present results show a wide dispersion of both $M L E S$ in

\footnotetext{
* Corresponding author.
} 
euchromatic chromosomal regions, including the B chromosome.

\section{MATERIAL AND METHODS}

\section{Animals, chromosome obtaining and DNA isolation}

Adult males and females of $A$. flavolineata were collected in the Parque Estadual Edmundo Navarro de Andrade in Rio Claro, São Paulo, Brazil, with the authorization of ICMBio SISBIO (process number 16009-1). Female gastric caeca were removed and fixed in a 3:1 ethanol: acetic acid solution for chromosome preparation according to Castillo et al. (2011). All specimens were stored in $100 \%$ ethanol for later DNA extraction. Genomic DNA was extracted using a the phenol-chloroform procedure of Sambrook $\&$ Russel (2001). To detect the presence of B chromosomes, we used a conventional staining procedure with $5 \%$ Giemsa for each individual.

\section{PCR amplification, sequence cloning and analysis}

The Mariner-like elements were amplified by the polymerase chain reaction (PCR) using genomic DNA obtained from $0 \mathrm{~B}$ individuals combining the primers MAR-188F (5' ATC TGR AGC TAT AAA TCA CT) and MAR-251R (5' CAA AGA TGT CCT TGG GTG TG), while the primer N6799 (5' GCC ATA TGT CGA GTT TCG TGC CA) was used alone because it anneals in the TIRs (Terminal Inverted Repeat) regions (Zhang et al., 2001; Lampe et al., 2003). PCR was performed in $10 \times$ PCR Rnx Buffer, $0.2 \mathrm{mM} \mathrm{MgCl}, 0.16 \mathrm{mM}$ dNTPs, $2 \mathrm{mM}$ of each primer $1 \mathrm{U}$ Taq DNA Polymerase (Invitrogen, San Diego, CA, USA) and 50-100 ng/ $\mu$ DNA. The PCR conditions included an initial denaturation step at $94^{\circ} \mathrm{C}$ for $5 \mathrm{~min}$, followed by 30 cycles at $94^{\circ} \mathrm{C}$ for $30 \mathrm{~s}$, an annealing temperature of $55^{\circ} \mathrm{C}$ for $30 \mathrm{~s}$, extension at $72^{\circ} \mathrm{C}$ for $80 \mathrm{~s}$ plus a final extension step at $72^{\circ} \mathrm{C}$ for $5 \mathrm{~min}$.

The PCR products were separated on a $1 \%$ agarose gel, whereafter the most evident DNA bands were purified using the kit Zymoclean ${ }^{\mathrm{TM}}$ Gel DNA Recovery Kit (Zymo Research Corp., The Epigenetics Company, USA) according to the manufacturer's recommendations. The purified PCR products were ligated to the plasmid pGEM-T (Promega, Madison, WI, USA), and the recombinant constructs then used to transform DH5 Escherichia coli competent cells. Positive clones were sequenced using an ABI Prism 3100 automatic DNA sequencer (Applied Biosystems, Foster City, CA, USA) with a Dynamic Terminator Cycle Sequencing Kit (Applied Biosystems).

The quality of the sequences was assessed using Geneious 4.8.5. Software (Drummond et al., 2009), and consensus sequences were used as an initial query against the collection deposited in The National Center for Biotechnology (NCBI) (http://www. ncbi.nlm.nih.gov) using the Blast search tool and CENSOR online software for the Repbase database (http://www.girinst.org/ repbase/) (Jurka et al., 2005). The consensus sequences were deposited in the GenBank database under the accession numbers KJ829354 and KJ829355.

\section{Fluorescent in situ hybridization}

FISH was performed according to Cabral-de-Mello et al. (2010) with probes labeled with digoxigenin-11-dUTP using PCR and were then detected using anti-digoxigenin Rhodamine (Roche, Mannheim, Germany). The probes for the isolated sequences were obtained from a pool of clones. FISH was performed in three distinct individuals for each probe and at least five metaphases were analyzed for each animal to confirm the patterns of hybridization.

The preparations were counterstained using 4', 6-diamidine-2'-phenylindole dihydrochloride (DAPI) and mounted in Vectashield (Vector, Burlingame, CA, USA). The chromosomes bp

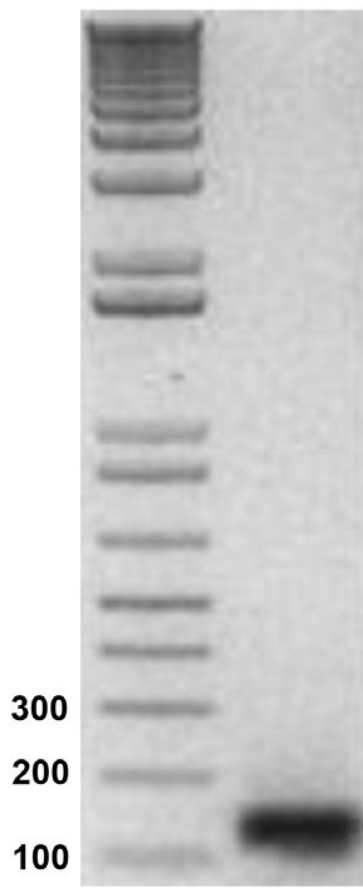

(a) bp

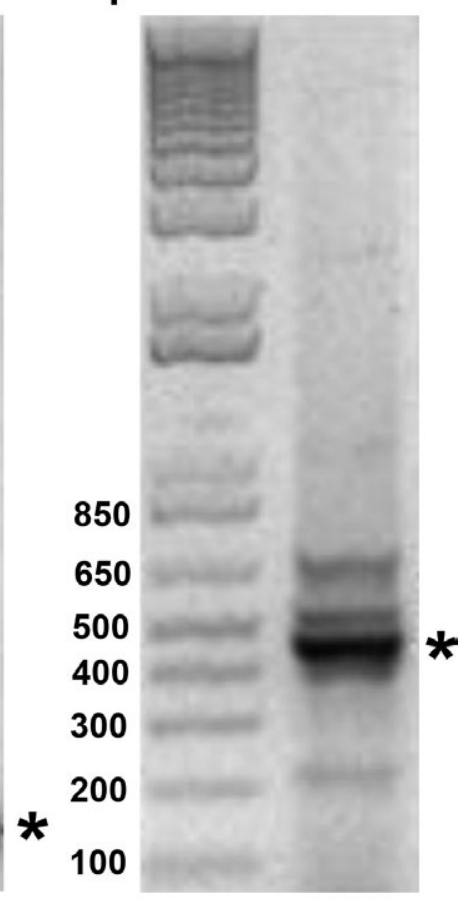

(b)
Fig. 1. Electrophoresis of PCR products after the amplification of (a) Afmarl (primers MAR-188F and MAR-251R) and (b) Afmar2 (primer N6799) elements using as template genomic DNA from A. flavolineata males with $0 \mathrm{~B}$ chromosome. Asterisks indicate the bands extracted for cloning.

and signals were analyzed using an Olympus microscope BX61 equipped with a fluorescence lamp and the appropriate filters. Photographs were taken and recorded using a DP70 cooled digital camera. At least ten metaphase spreads were photographed for each probe. Images were obtained in grey scale and then pseudocolored, optimized for brightness and contrast and merged using Adobe Photoshop CS2.

\section{RESULTS}

PCR amplification using the primers MAR-188F/MAR$251 \mathrm{R}$ revealed a unique band of approximately $150 \mathrm{bp}$ (Fig. 1a); primers N6799 amplified multiple bands and the strongest band, which was approximately 470 bp was examined using other techniques (Fig. 1b). The sequencing and Blast search revealed that the consensus sequence (from five clones) of the $150 \mathrm{bp}$ band was essentially similar to the Mariner elements isolated from, for example, the beetles, Diabroctis mimas L. (JX976934: query cover 37\%, identity 97\%) and Coprophanaeus ensifer Germar (Coleoptera: Scarabaeidae) (JX976928: query cover 22\%, identity 97\%), the earwig, Forficula auricularia L. (Dermaptera: Forficulidae) (AY226502: query cover 33\%, identity 100\%) and the honeybee, Apis mellifera L. (Hymenoptera: Apiidae) (AY226477: query cover 33\%, identity $100 \%$ ); this sequence was named Afmarl. With regard to the 470 bp sequence (named Afmar2), the consensus of six clones revealed similarity with the $P$ ogo- $T c 1$ element from the pufferfish, Takifugu rubripes (Temminck \& Schlegel) (Actinopterygii: Tetraodontiformes: Tetraodontidae) (simi- 


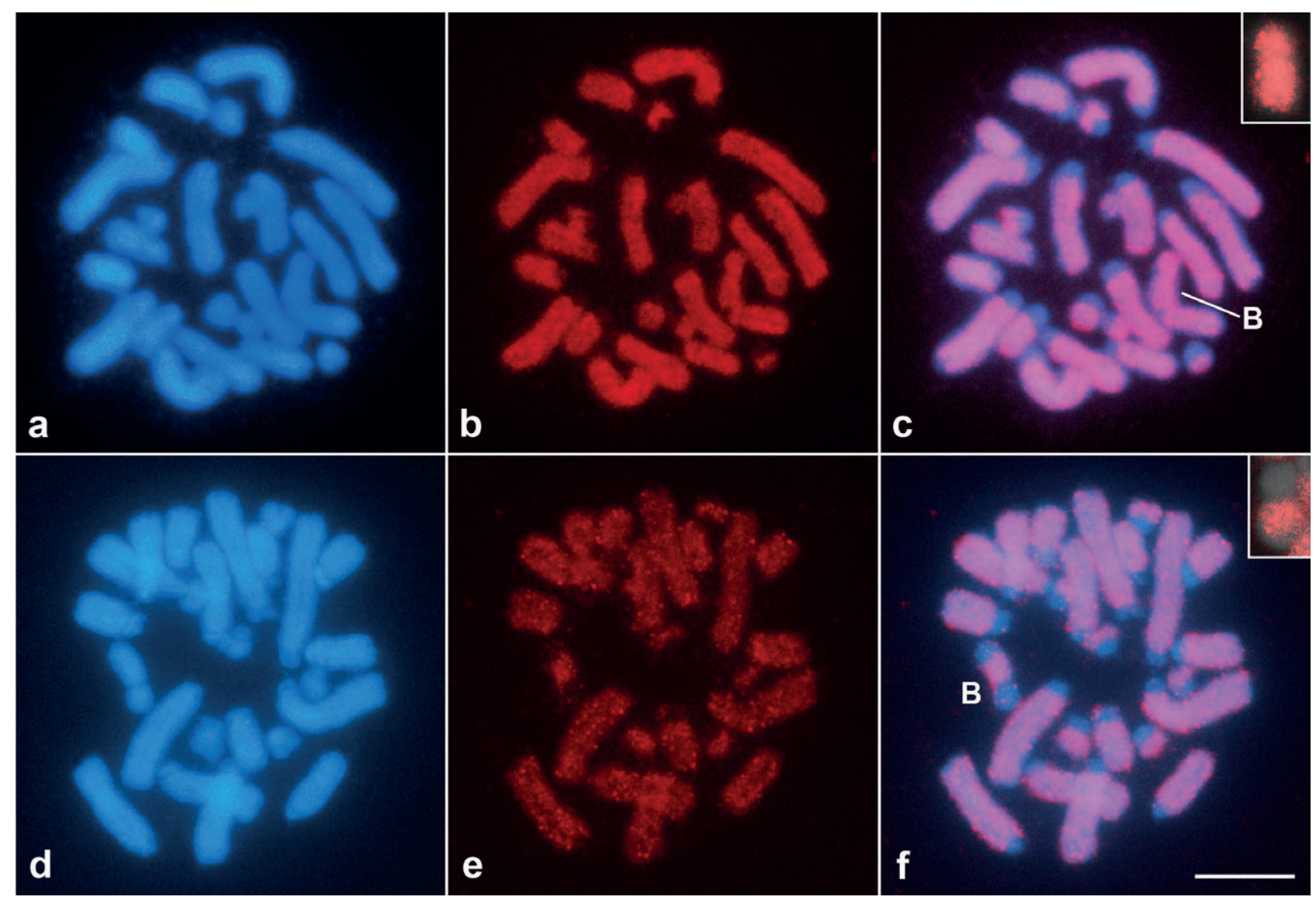

Fig. 2. FISH mapping for (a-c) Afmarl and (d-f) Afmar2 in mitotic metaphase plates of females that harbour one B chromosome. a, $\mathrm{d}$ - DAPI; b, e - signals of the used probes; c, f - DAPI + signals. The B chromosome is indicated in each cell and the insets in (c, f) highlight the MLEs distribution in this chromosome. Note the absence of signals in the centromeric regions extending to the short arms of the A chromosomes that correspond to the heterochromatic blocks. Bar $=5 \mu \mathrm{m}$.

larity 65\%), which has been deposited in Repbase (Smit, 2002). The both sequences, Afmarl and Afmar2, are defective, considering their size in relation to canonical Mariner elements.

Chromosomal mapping of Afmarl and Afmar2 by FISH revealed their enrichment in euchromatic regions of all $\mathrm{A}$ complement chromosomes. No signals were observed for the regions that corresponded to heterochromatin blocks, e.g., the pericentromeric region extending to the short arm (Fig. 2). Afmarl was dispersed throughout the B chromosome (Fig. 2c), whereas Afmar 2 was located only in the proximal/interstitial position of the long arm (Fig. 2f).

\section{DISCUSSION}

The organization and composition of TEs in the genome of grasshopper species are poorly known, and the chromosomal mapping of distinct elements has been performed to date in Eyprepocnemis plorans (Charpentier) (Orthoptera: Acrididae) (Montiel et al., 2012). Considering that grasshoppers have large genomes, reaching up to $\sim 17 \mathrm{pg}$ in Podisma pedestris (L.) (Orthoptera: Acrididae) (Westerman et al., 1987), and that TEs could be directly involved in increasing genome size in eukaryotes, grasshopper genomes potentially harbour a large number and diversity of these elements (Kidwell, 2002; Biémont \& Vieira, 2006; Feschotte \& Pritham, 2007; Hua-Van et al., 2011).
Recently, Wang et al. (2014) analyzed the sequenced genome of the migratory locust, Locusta migratoria (L.) (Orthoptera: Acrididae) and identified large quantity of mobile elements, i.e. among the $6.5 \mathrm{~Gb}$ of DNA in the $L$. migratoria genome, $\sim 24 \%$ were found to be transposons and $17 \%$ LINE retrotransposons. The occurrence of TEs in eukaryotic genomes is well represented by MLES, which have been isolated from some animal groups. These elements are primarily non-functional due to occurrence of distinct mutations (see for example Green \& Frommer, 2001; Kumaresan \& Mathavan, 2004; Rezende-Teixeira et al., 2008), as in the case of A. flavolineata, in which the copies of MLEs isolated are defective.

As observed in E. plorans, we noted the occurrence of TEs enriched in euchromatic areas (Montiel et al., 2012). This distribution pattern is uncommon, as the preferential sites for TEs are in general the heterochromatic regions with a typical low gene density (Dimitri et al., 2003). In Orthoptera, the reasons for a high genomic distribution of MLEs detected by FISH are not clear; however, the similar distribution patterns of these elements in euchromatin noted in this work, as well as in E. plorans, reinforces the view that there is a preferential insertion of such sequences in euchromatic regions. Such results lead to two main conclusions: (i) enrichment of TEs in euchromatic regions is a common feature of grasshopper chromosomes; and (ii) 
the high extent of TEs amplification and mobility is common in this group. It has been claimed considering that the two species studied until now are distantly phylogenetically related; however, we cannot exclude the possibility of this TEs distribution pattern as a particular characteristic for the TEs studied, e.g., amplification in specific chromosomal regions, producing multiple arrays, followed by dispersion at other chromosomal sites. Recently, Montiel et al. (2012) suggested that the occurrence of TEs in the euchromatin of E. plorans was tolerated because of its large genome (10.16 Gb, Ruiz-Ruano et al., 2011) and because TEs have insertion sites in pseudogenes, intergenic spacers and other repetitive sequences. The study of the $L$. migratoria sequenced genome revealed that the increase in intron size may be partly caused by TE invasion (Wang et al., 2014). These proposed scenarios could also explain the abundance of TEs in A. flavolineata, given the large genomes of grasshoppers.

The paucity of TEs in the heterochromatin of $A$. flavolineata may be attributable to the occurrence of other sequences in these regions; for example, H3 histone genes have been observed in all centromeres, and $18 \mathrm{~S}$ rDNA occupies some heterochromatic areas that may have avoided invasion by the studied MLE TEs. These areas are also enriched for other moderately and highly repetitive sequences, as corroborated by $C_{0} t-1$ DNA mapping (Bueno et al., 2013); however, we cannot completely rule out the possibility of TE copies in genomic regions that have not been revealed by FISH. This absence also could indicate that these elements have not played a role in either autosome or sex chromosome heterochromatin organization in the studied species, as proposed for E. plorans (Montiel et al., 2012). In contrast, Mamestra brassicae (L.) (Lepidoptera: Noctuidae) displays heterochromatic regions of its sex chromosomes that are enriched with an MLE (Mandrioli, 2003).

B chromosomes are a propitious target for TEs accumulation due to their general lack of recombination, whilst the enrichment of TEs in the euchromatic $\mathrm{B}$ chromosome of $A$. flavolineata accords with the distribution of these elements in the A complement. Some other cases of TE enrichment in B chromosomes have also been reported, such as for Gypsy retrotransposons in fishes, i.e. the common bleak, Alburnus alburnus (L.) (Actinopterygii: Cypriniformes: Cyprinidae) (Ziegler et al., 2003) and Rex 1 and Rex3 retrotransposons in the Zebra Obliquidens, Astatotilapia latifasciata Regan (Actinopterygii: Perciformes: Cichlidae) (Fantinatti et al., 2012). LOA-like non-LTR retrotransposons have been reported in the scarab beetle, Coprophanaeus cyanescens Olsufieff (Coleoptera: Scarabaeidae) (Oliveira et al., 2012), and the BALTR element has been reported in maize, Zea mays L. (Poaceae) (Lamb et al., 2007). In addition, the Revolver element has been reported in rye, Secale cereale L. (Poaceae) (Marques et al., 2013), and Gypsy retrotransposons in the fungus Nectria haematococca (Berk. \& Broome) Samuels \& Rossman 1999 (Sordariomycetes: Hypocreomycetidae: Hypocreales: Nectriaceae) (Coleman et al., 2009). In contrast, the B24 and B2 chromosomes of
E. plorans exhibit a paucity of mapped transposable elements, i.e. only small interstitial bands, which according to Montiel et al. (2012) have probably participated in B chromosome mutation/instability in this species. In $\mathrm{A}$. $\mathrm{fla}$ volineata, the enrichment of the two MLEs in the B chromosome also suggests their possible role in the origin/differentiation of this chromosome. According to Bueno et al. (2013), the submetacentric B chromosome observed in $A$. flavolineata was generated via isochromosome formation, followed by a pericentric inversion or the enlargement of one arm. The distribution of Afmar2 in the B chromosome, which is restricted to the proximal/interstitial area of the large arm, suggests its involvement in the differentiation of this chromosome, specifically in the expansion of one arm.

Considering that ancient TEs have a tendency toward accumulation in euchromatin, the ubiquitous occurrence of the two MLEs in this genomic area of A. flavolineata argues for a remarkable amplification of this element in the past that preceded the origin of the B chromosome and may have played a role in its evolutionary history. The analysis of other A. flavolineata populations harbouring B chromosomes using TEs as markers could shed light on the evolutionary dynamics of this polymorphism in a geographical context, as well as the isolation of other classes of TEs. Studies of additional Orthopteran species will also doubtless contribute to our knowledge of TEs and their impact on the genomes of this group.

ACKNOWLEDGEMENTS. This study was supported by the Fundação de Amparo a Pesquisa do Estado de São Paulo, FAPESP (2011/19481-3), Conselho Nacional de Desenvolvimento Científico e Tecnologico, CNPq (475308/2011-5) and PROPE-UNESP. The scholarships of O.M. Palacios-Gimenez and D. Bueno were granted by FAPESP (2012/01421-7 and 2011/18028$3)$. We thank H.D. Loxdale for his helpful editorial comments.

\section{REFERENCES}

Augé-Gouillou C., Bigot Y., Poller N., Hamelin M.H., Meunier-Rotival M. \& Periquet G. 1995: Human and other mammalian genomes contain transposons of the mariner family. FEBS Letters 368: 541-546.

Bí́MONT C. 2010: A brief history of the status of transposable elements: from junk DNA to major players in evolution. - Genetics 186: 1085-1093.

Bí́mont C. \& Vieira C. 2006: Genetics: Junk DNA as an evolutionary force. - Nature 443: 521-524.

Böhne A., Brunet F., Galiana-Arnoux D., Schultheis C. \& Volff J.N. 2008: Transposable elements as drivers of genomic and biological diversity in vertebrates. - Chromosome Res $\mathbf{1 6}$ : 203-215.

Bueno D., Palacios-Gimenez O.M. \& Cabral-de-Mello D.C. 2013: Chromosomal mapping of repetitive DNAs in Abracris flavolineata reveal possible ancestry for the B chromosome and surprisingly $\mathrm{H} 3$ histone spreading. — PLOS ONE 8: e66532.

Cabral-de-Mello D.C., Moura R.C. \& Martins C. 2010: Chromosomal mapping of repetitive DNAs in the beetle Dichotomius geminatus provides the first evidence for an association of 5S rRNA and histone $\mathrm{H} 3$ genes in insects, and repetitive DNA similarity between the B chromosome and A complement. Heredity 104: 393-400. 
CAMACHO J.P.M. 2005: B chromosomes. In Gregory T.R. (ed.): The Evolution of the Genome. Elsevier, Amsterdam, New York, pp. 223-286.

Castillo E.R., TAfFarel A. \& Martí D.A. 2011: Una técnica alternativa para el caritiopado mitótico en saltamontes: bandeo $\mathrm{C}$ y fluorescente en Adimantus ornatissimus (Orthoptera: Acrididae). - Rev. Cienc. Tecnol. 16: 31-35.

Charles M., Belcram H., Just J., Huneau C., Viollet A., Couloux A., Segurens B., Carter M., Huteau V., Coriton O., Appels R., Samain S. \& Chalhoub B. 2008: Dynamics and differential proliferation of transposable elements during the evolution of the B and A genomes of wheat. - Genetics 180: 1071-1086.

Coleman J.J., Rounsley S.D., Rodriguez-Carres M., Kuo A., Wasmann C.C., Grimwood J., Schmutz J., Taga M., White G.J., Zhou Z., Schwartz D.C., Freitag M., Ma L., Danchin E.G.J., Henrissat B., Coutinho P.M., Nelson D.R., Straney D., Napoli C.A., Barker B.M., Gribskov M., Rep M., KrokeN S., Molnár I., Rensing C., Kennell J.C., Zamora J., Farman M.L., Selker E.U., Salamov A., Shapiro H., Pangilinan J., Lindquist E., Lamers C., Grigoriev I.V., Geiser D.M., Covert S.F., Temporini E. \& Van Etten H.D. 2009: The genome of Nectria haematococca: contribution of supernumerary chromosomes to gene expansion. - PLoS Genet. 5: e1000618.

Dimitri P., Jukanovic N. \& ArCÀ B. 2003: Colonization of heterochromatic genes by transposable elements in Drosophila. - Mol. Biol. Evol. 20: 503-512.

Doolittle W.F. \& Sapienza C. 1980: Selfish genes, the phenotype paradigm and genome evolution. - Nature 284: 601-603.

Drummond A.J., Ashton B., Cheung M., Heled J., Kearse M. Moir R., Stones-Havas S., Sturrock S., Thierer T. \& WiLSON A. 2009: Geneious v4.8.5, Available from http://www.geneious.com

Fantinatti B.E.A., Mazzuchelli J., Valente G.T., Cabral-DeMello D.C. \& Martins C. 2012: Genomic content and new insights on the origin of the B chromosome of the cichlid fish Astatotilapia latifasciata. — Genetica 139: 1273-1282.

Feschotte C. \& Pritham E.J. 2007: DNA transposons and the evolution of eukaryotic genomes. - Annu. Rev. Genet. 41: 331-368.

Feschotte C. \& Wessler S.R. 2002: Mariner-like transposases are widespread and diverse in flowering plants. - Proc. Natl. Acad. Sci. USA 99: 280-285.

Green C.L. \& Frommer M. 2001: The genome of the queensland fruit fly Bactrocera tryoni contains multiple representatives of the mariner family of transposable elements. - Insect Mol. Biol. 10: 371-386.

Houben A., Banaei-Moghaddam A.M. \& Klemme S. 2013: Biology and evolution of B chromosomes. In Leitch I.J., Greilhuber J., Dolezel J. \& Wendel J. (eds): Plant Genome Diversity. Vol. 2. Physical Structure, Behaviour and Evolution of Plant Genomes. Springer, Wien, pp. 149-165.

Hua-Van A., Le Rouzic A., Boutin T.S., Filée J. \& Capy P. 2011: The struggle for life of the genome's selfish architects. - Biology Dir 6: 19.

Hurst G.D.D. \& WERREN J.H. 2001: The role of selfish genetic elements in eukaryotic. - Nature Rev. Genet. 2: 597-606.

Jacobs G., Dechyeva D., Menzel G., Dombrowski C. \& Schmidt T. 2004: Molecular characterization of Vulmar1, a complete mariner transposon of sugar beet and diversity of mariner and En/Spm-like sequences in the genus Beta. - Genome 47: $1192-1201$

Jurka J., Kapitonov V.V., Pavlicek A., Klonowski P., Kohany O. \&WALICHIEWICZ J. 2005: Repbase update, a database of eukaryotic repetitive elements. - Cytogenet. Gen. Res. 110: 462-467.
KAPITONOV V.V. \& JURKA J. 2008: A universal classification of eukaryotic transposable elements implemented in Repbase. Nature Rev. Genet. 9: 411-412.

KAZAZIAN JR H.H. 2004: Mobile elements: drivers of genome evolution. - Science 303: 1625-1632.

Kidwell M.G. 2002: Transposable elements and the evolution of genome size in eukaryotes. - Genetica 115: 49-63.

Kumaresan G. \& Mathavan S. 2004: Molecular diversity and phylogenetic analysis of mariner-like transposons in the genome of the silkworm Bombyx mori. — Insect Mol. Biol. 3: 259-271.

Lamb J.C., Riddle N.C., Cheng Y.M., Theuri J. \& Birchler J.A. 2007: Location and transcription of a retrotransposon-derived element on the maize B chromosome. - Chromosome Res 15: 383-398.

Lander E.S., Linton L.M., Birren B., Nusbaum C., Zody M.C., Baldwin J., Devon K., Dewar K., Doyle M., FitzHugh W., Funke R., Gage D., Harris K., Heaford A., Howland J., Kann L., Lehoczky J., LeVine R., McEwan P., McKernan K., Meldrim J., Mesirov J.P., Miranda C., Morris W., NaYlor J., Raymond C., Rosetti M., Santos R., Sheridan A., Sougnez C., Stange-Thomann N., Stojanovic N., Subramanian A., Wyman D., Rogers J., Sulston J., Ainscough R., Beck S., Bentley D., Burton J., Clee C., Carter N., Coulson A., Deadman R., Deloukas P., Dunham A., Dunham I., Durbin R., French L., Grafham D., Gregory S., Hubbard T., Humphray S., Hunt A., Jones M., Lloyd C., McMurray A., Matthews L., Mercer S., Milne S., Mullikin J.C., Mungall A., Plumb R., Ross M., Shownkeen R., Sims S., Waterston R.H., Wilson R.K., Hillier L.W., McPherson J.D., Marra M.A., Mardis E.R., Fulton L.A., Chinwalla A.T., Pepin K.H., Gish W.R., Chissoe S.L., Wendl M.C., Delehaunty K.D., Miner T.L., Delehaunty A., Kramer J.B., Cook L.L., Fulton R.S., Johnson D.L., Minx P.J., Clifton S.W., Hawkins T., Branscomb E., Predki P., Richardson P., Wenning S., Slezak T., Doggett N., Cheng J.F., Olsen A., Lucas S., Elkin C., Uberbacher E., Frazier M., Gibbs R.A., Muzny D.M., Scherer S.E., Bouck J.B., Sodergren E.J., Worley K.C., Rives C.M., Gorrell J.H., Metzker M.L., Naylor S.L., Kucherlapati R.S., Nelson D.L., Weinstock G.M., SAKaki Y., Fujiyama A., Hattori M., Yada T., Toyoda A., Itoh T., Kawagoe C., Watanabe H., Totoki Y., Taylor T., Weissenbach J., Heilig R., Saurin W., Artiguenave F., Brottier P., Bruls T., Pelletier E., Robert C., Wincker P., Smith D.R., Doucette-Stamm L., Rubenfield M., Weinstock K., Lee H.M., Dubois J., Rosenthal A., Platzer M., Nyakatura G., Taudien S., Rump A., Yang H., Yu J., Wang J., Huang G., Gu J., Hood L., Rowen L., Madan A., Qin S., Davis R.W., Federspiel N.A., Abola A.P., Proctor M.J., Myers R.M., Schmutz J., Dickson M., Grimwood J., Cox D.R., Olson M.V., Kaul R., Raymond C., Shimizu N., Kawasaki K., Minoshima S., Evans G.A., Athanasiou M. \& Schultz R. 2001: Initial sequencing and analysis of the human genome. $-\mathrm{Na}$ ture 409: 860-921.

Langin T., CAPY P. \& Daboussi M.J. 1995: The transposable element impala, a fungal member of the Tc1-mariner superfamily. - Mol. Gen. Genet. 246: 19-28.

Lampe D.J., Churchill M.E.A. \& Robertson H.M. 1996: A purified mariner transposase is sufficient to mediate transposition in vitro. - EMBO J. 15: 5470-5479.

LAmpe D.J., Witherspoon D.J., SOto-Adames F.N. \& Robertson H.M. 2003: Recent horizontal transfer of mellifera subfamily Mariner transposons into insect lineages representing four different orders shows that selection acts only during horizontal transfer. - Mol. Biol. Evol. 20: 554-562. 
MANDRIOLI M. 2003: Identification and chromosomal localization of mariner-like elements in the cabbage moth Mamestra brassicae (Lepidoptera). - Chromosome Res. 11: 319-322.

Marques A., Banaei-Moghaddam A.M., Klemme S., Blattner F.R., Niwa K., Guerra M. \& Houben A. 2013: B chromosomes of rye are highly conserved and accompanied the development of early agriculture. - Ann. Bot. 112: 527-534.

Montiel E.E., Cabrero J., Camacho J.P.M. \& López-León M.A. 2012: Gypsy, RTE and Mariner transposable elements populate Eyprepocnemis plorans genome. - Genetica 140: 365-374.

Oliveira S.G., Moura R.C. \& Martins C. 2012: B chromosome in the beetle Coprophanaeus cyanescens (Scarabaeidae): emphasis in the organization of repetitive DNA sequences. BMC Genet. 13: 96.

Orgel L.E. \& CRICK F.H.C. 1980: Selfish DNA: the ultimate parasite. - Nature 284: 604-607.

Osanai-Futahashi M., Suetsugub Y., Mita K. \& Fujiwara H. 2008: Genome-wide screening and characterization of transposable elements and their distribution analysis in the silkworm Bombyx mori. — Insect Mol. Biol. 38: 1046-1057.

Plasterk R.H.A., Izsvák Z. \& Ivics Z. 1999: Resident aliens: the Tc1/mariner superfamily of transposable elements. - Trends Genet. 15: 326-332.

Rezende-Teixeira P., Siviero F., Andrade A., Santelli R.V. \& Machado-Santelli G.M. 2008: Mariner-like elements in Rhynchosciara americana (Sciaridae) genome: molecular and cytological aspects. - Genetica 133: 137-145.

Ruiz-Ruano F.J., Ruiz-Estévez M., Rodríguez-Pérez J., LóPez-Pino J.L., Cabrero J. \& CAMacho J.P.M. 2011: DNA amount of $\mathrm{X}$ and $\mathrm{B}$ chromosomes in the grasshoppers Eyprepocnemis plorans and Locusta migratoria. - Cytogenet. Gen. Res. 134: $120-126$.

Sambrook J. \& Russel D.W. 2001: Molecular Cloning. A Laboratory Manual. Cold Spring Harbor Laboratory Press, Cold Spring Harbor, New York, 999 pp.
Sinzelle L., Chesneau A., Bigot Y., Mazabraud A. \& Pollet N. 2006: The mariner transposons belonging to the irritans subfamily were maintained in Chordate genomes by vertical transmission. - J. Mol. Evol. 62: 53-65.

Sмiт A.F. 2002: Initial survey of interspersed repeats in Takifugu rubripes. - Repbase Reports 2: 56-56.

Wang X., Fang X., Yang P., Jiang X., Jiang F., Zhao D., Li B., Cui F., Wei J., Ma C., Wang Y., He J., Luo Y., Wang Z., Guo X., Guo W., Wang X., Zhang Y., Yang M., Hao S., Chen B., Ma Z., Yu D., Xiong Z., Zhu Y., Fan D., Han L., Wang B., Chen Y., Wang J., Yang L., Zhao W., Feng Y., Chen G., Lian J., Li Q., Huang Z., Yao X., Lv N., Zhang G., Li Y., WANG J., WANG J., Zhu B. \& Kang L. 2014: The locust genome provides insight into swarm formation and long-distance flight. - Nature Commun 5: 2957.

Westerman M., Barton N.H. \& Hewitt G.M. 1987: Differences in DNA content between two chromosomal races of the grasshopper Podisma pedestris. - Heredity 58: 221-228.

Wicker T., Sabot F., Hua-Van A., Bennetzen J.L., Capy P., Chalhoub B., Flavell A., Leroy P., Morgante M., Panaud O., Paux E., SanMiguel P. \& Schulman A.H. 2007: A unified classification system for eukaryotic transposable elements. - Nature Rev. Genet. 8: 973-982.

Witherspoon D.J. \& Robertson H.M. 2003: Neutral evolution of ten types of mariner transposons in the genomes of Caenorhabditis elegans and Caenorhabditis briggsae. - J. Mol. Evol. 56: 751-769.

Zhang L., Dawson A. \& Finnegan D.J. 2001: DNA-binding activity and subunit interaction of the mariner tranposase. - Nucl. Acid Res. 29: 3566-3575.

Ziegler C.G., Lamatsch D.K., Steinlein C., Engel W., Schartl M. \& Schmid M. 2003: The giant B chromosome of the cyprinid fish Alburnus alburnus harbours a retrotransposonderived repetitive DNA sequence. - Chromosome Res 11: 23-35.

Received November 29, 2013; revised and accepted March 6, 2014 Prepublished online May 27, 2014 